\title{
Environmental education in Slovakia in the context of ethics and ethics education
}

\author{
Adela Lešková Blahová
}

\begin{abstract}
This paper focuses on the current state of environmental education within formal education in Slovakia, emphasising its methodology and weak points. The author aims to identify the place and role of philosophicalethical theory within environmental education, which is an integral part of ethics education. What concrete knowledge, skills and instruments of both ethics and philosophy can (should) a teacher of ethics education put into effect when teaching environmental-educational topics? Before answering this question the place of environmental education within the broader context of moral education will be explored.
\end{abstract}

Keywords: environmental education, ethics education, moral education, critical thinking, creativity, interdisciplinary, philosophical justification, ethical argumentation

\section{Introduction}

Environmental education in Slovakia has been part of formal education, at both primary and secondary school education, since the 1990s. In this time, it has gone through several conceptual changes. The current model of environmental education was approved in 2006 with education for sustainable development as its priority. This conceptual change was, in 2008, transferred into the National Education Program and environmental education was redefined as a so called cross-sectional topic (it intersects with various educational areas). From September 1, 2015 a new National Educational Program for individual levels of education has been in effect. However, it has not brought about any significant modifications to environmental education at neither primary nor secondary school education. Environmental education has remained a cross-sectional topic; it is a part of syllabi of different subjectls.

\section{Reservations about the current concept of environmental education in Slovakia}

In official pedagogical documents (in the National Education Program), the expected outcomes of environmental education are the understanding and internalizing the idea of sustainable development in the context of a complex (ecological, economic and social levels) relationship between people, culture and nature. Emphasis has been placed on interconnection, deepening and systematization of knowledge, special habits and skills in order to understand the global essence of any ecological issue (NEP Environmental education, 2009 , p. 2); followed by the intention to realize an interpretive model ${ }^{1}$ of environmental education in Slovakia. This aim is, at first glance, suggested by adjectives such as sustainable,

\footnotetext{
${ }^{1}$ Ian Robottom, Paul Hart and Joy A. Palmer have introduced three basic methodological approaches to understanding and realization of environmental education. Jan Činčera has conveniently recapitulated them in Czech. To put it simply, each of them can be characterized by a prevailing educational aim; a development of either knowledge or skills or a formation of attitudes and values. They talk about positivistic, critical and interpretive models. The third paradigm of environmental education is the so called "interpretive model" with the main thesis "to live and to interpret". We environmentally educate through in - from natural environment with an emphasis on global character of a given issue (the most intensive relationship to global education). The aesthetical aspect of learning and appreciation of nature dominates here and emphasis is on the development of communicative and learning skills of a student (Činčera, 2007, pp. 15-52; Lešková Blahová, 2015, pp. 117121).
} 
global, systematic and complex. However, if we ask to what extent can formal education in Slovakia, particularly the educational programmes ISCED2, ISCED $3,{ }^{2}$ fulfil the other features of the interpretive approach towards environmental education in practice, then our answer will not be univocal predominantly due to the use of traditional didactic methods, methodology and methodics, which are more typical for the positivistic model of environmental education. To sum up, the concept of environmental education in schools in Slovakia has been predominantly focused on education or knowledge in the spirit of positivism. ${ }^{3}$

However, in the word of Aristotle, if we wish to live well it is not sufficient to know what the good is (Aristotle, 2000, book 6). It is important to do good rather than only to know what the good is. And the critical model (to a lesser extent also the interpretive model) of environmental education is related to ethics and the moral dimension of students' personalities in the most vivid way. If we understand environmental education in a complex way (formation of a complex personality of people, including their knowledge, skills and attitudes and value orientation), then it is not sufficient to realize it in the sense of "education of protection" which promotes law-abidingness (concerning nature and natural environment protection laws), joining of protective organizations, protection of our closest regions, voting (politically) correctly, recycling, etc. (Leopold, 1995, pp. 237-240). An increase in being informed about the laws of life on Earth, of the character of environmental crises and possibilities of ecologically favourable lifestyle does not guarantee a real change in our behaviour (so called environmental literacy). The majority of the population (under the pressure of medialisation of environmental issues) know and can correctly define concepts such as the green-house effect, the ozone hole, global warming, population explosion or recycling. In spite of this knowledge, consumer lifestyle emphasising satisfaction of current (predominantly material) needs and incorrectly defining our quality of life still prevails in our society.

My next reservation is related to the conceptual (thematic) focus of environmental education in Slovakia. Taking into account still valid official documents, this education shall be aimed at the following topics and problems: nature and landscape protection; elements of natural environment; natural resources and their use and protection; human activities and problems of natural environment; relationship of people to the environment (NEP Environmental education, 2009, pp. 4-5). Together with some members of the scientific community (an initiative of the non-governmental and non-profit organization Śpirála, especially Richard Medal, Silvia Milová, Jana Klocoková and others), I understand this focus in a reductionist way, leaning towards formalism. Such thematic focus of environmental education stirs an idea of ecologization or ecological dominance regarding interpretation of a given issue, resulting in an (almost) absent moral-educational (mainly axiological) or social dimension of environmental education.

Modern environmental education can be defined more broadly: as an education with ethical and social dimensions. In other words, it can be defined in an interdisciplinary manner - focusing on relationships and interconnections, reflecting the development of the world and humane society, including topics of value laden behaviour, philosophical, spiritual, civic and community issues as well as ethical, moral and social topics. Issues of justice and equality, democratization, security and world peace, poverty and illiteracy suppression, respect for

\footnotetext{
${ }^{2}$ The programs are chosen deliberately. Ethics education is realized as a compulsory elective subject within these programmes.

${ }^{3}$ And yet, an aspiration towards hybridization of environmental education in the spirit of interpretivism, also (but less) of criticism can be observed. A special case presents education at nurseries and junior level primary schools where learning through play shall be practised (taking into account the psycho-motoric level of children). In environmental education, within ISCED0 and ISCED1, an interpretive approach to environmental education may certainly prevail over a positivistic one.
} 
human rights, responsible citizenship, rational and conscious production and consumption, solidarity and a life in accordance with nature, self-sufficiency and adaptability in the sense of a flexible reaction to changes in life and social conditions but also issues regarding changes of value hierarchy and applicability of theories of natural environment protection and sustainable development into practice shall be included (Milová, Medal \& Klocoková, 2012, pp. 19, 7778). Incorporation of these global issues calls for a holistic approach. Along this line, environmental education is close to global education.

\section{Environmental education as part of moral education}

I understand environmental education as a part (constituent) of a broader concept of moral education. Moral education "leads to an ability to think autonomously morally, to evaluate, to act and to take responsibility for our actions” (Platková Olejárová, 2010, p. 155). It focuses on the formation of the personality and character (character qualities, attitudes, moral consciousness and sense) of a person in the context of desired moral behaviour. I am even of the opinion that environmental education should be understood in the context of the creativehumanistic model of education by the well-known and respected Slovak psychologist and university teacher Miron Zelina. The creative-humanistic system of education is a systematic approach to education aiming at enhancing not only the cognitive-rationalistic dimension with creativity or creative thinking as its apex, but also the non-cognitive - emotional dimension (focus on humanism, humanization of a person) of a child's/person's personality. To achieve this, it puts to use the special, so called non-cognitive (out-of experience) functions of personality development, namely: cognitivization, emotionalization, motivation, socialization, self-regulation and creativization (the so called CEMSAC system) (Zelina, 2010; 1997).

To educate environmentally stands for, among other things, the cultivation of the moral personality of a person and enhancement of their moral attitudes and consciousness in the manner of responsible and environmentally favourable behaviour. An axiological frame of such behaviour is made up of several values, such as:

- respect and reverence for nature, the value of life and dignity in general;

- acknowledgement of solidarity, tolerance, empathy and sympathy in a broader (environmental) sense;

- acceptance of (ecological) humanism and responsibility,

- equality as justice,

- preventive carefulness and foresight in human acting with regards to nature and life in the broadest sense,

- virtuous behaviour in the spirit of care (for nature and natural environment); as well as a moderate approach towards nature, for example modest and voluntary (self)constraint, non-consumer lifestyle or the concept of sustainable development (Lešková Blahová, 2011, pp. 547-548; Lešková Blahová, 2014, pp. 110-119; Lešková Blahová, 2015, pp. 41-49).

Environmental education understood in this manner would not be complete without the formation of ecological (environmental), legal, social-economic, political and aesthetical consciousness alongside the moral dimension of a person's personality (in our case, always in the context of human-culture-nature reflection). We talk about complex environmental literacy, including cognitive as well as non-cognitive (perceptive, affective) and behavioural dimensions of a person's personality. I am of the opinion that global education is an attempt at a more complex formation of a person's personality also because it deals with topics such as migration; peace and conflict; political power; peace and human rights; sustainable development and the natural environment; natural resources; consumption and production; food and agriculture; global economics and international trade; diversity and intercultural relations; poverty; health and well-being and others (Zajac \& Návojský, 2014). The majority 
of topics do indeed overlap with the ethical and moral dimension of the environmental agenda and thus cover the needs of society at present or react to current moral challenges (in social practice, scientific and technological progress, etc.) in a more complex way. The holistic and systemic approach to education (also in an environmental context) is the basic advantage of global education. A precondition of such a broad concept of environmental education is a change in our thinking, in our way of reasoning and in the overall idea of a human and nonhuman world and philosophical-ethical reflection with its tools, mainly critical thinking and rational argumentation which should naturally complement a non-cognitive (intuitive) perception and appreciation of the surrounding nature (life), can be extremely helpful here. In the words of Hana Librová, we need more than just improvisational attitudes; we need to rely on something (Librová, 1994, p. 159). This can be the place for an explanatory and theoretical framework of ethics and philosophy, which could enable us to move the realization of environmental education from a clearly positivist perspective to its hybrid models (in the spirit of interpretivism and criticism).

\section{Conclusion}

What does it mean in practice? What knowledge, skills and other ethical-philosophical tools can a teacher of ethics education ${ }^{4}$ put into practice when teaching environmental topics? It is certainly important to build on the knowledge gained during ethics or the study of ethics education, with the main focus on courses on philosophical or applied ethics (for example: rudiments of ethics and moral education, introduction to ethics, systemic ethics, cultural anthropology but also didactics of ethics education, introduction to applied ethics, introduction to bioethics, social and political ethics, consumer ethics and environmental education). For sure, also the experience gained during pedagogical praxis is important.

In general, ethics and ethics education is about such mental practices as analysis, synthesis, comparison, induction and deduction, convergent and divergent thinking but most of all critical dialectic-non-linear thinking and abstraction. This (divergent) thinking is "typical for creation of alternatives, hypotheses, exploration, speculation, possibilities evaluation and creation of new ideas and approaches" (Zelina, 1997, p. 61). Enhancement of pupils' critical thinking means supporting their ability to express their own ideas as well as the development and demonstration of their own identity.

Apart from other things, it is necessary (in order to get beyond a positivistic framework of environmental education) to avoid any prejudice and stereotype in thinking; it is necessary to be exceptional, flexible and creative. In this sense, ethical education is closely related to the creative-humanistic model of Zelina. Creativity is not only about our ability to think, argue, re-evaluate or assess originally logically (non-conformist thinking) but predominantly about being sensitive (problem-oriented sensitivity) and open to the world. With regards to ethics and ethics education we talk about a need to focus on positive and creative approaches to problems as it is divergent thinking that is the basis of creativity. Creative thinking requires understanding and respect for human dignity and humanity, freedom, tolerance and cooperation. Openness to the world is a precondition of an interest (opposed to indifference) in public issues and of active participation in similar issues.

In so much that environmental topics go beyond ecology and environmentalist scopes, it is necessary to approach environmental education from the interdisciplinary (synthetic-integral relevance of interdepartmental relationships when exploring environmental issues) point of view. To present environmental education topics through balanced knowledge input from ecology and environmentalism, ethics and philosophy, culturology, anthropology, sociology and law and the like.

\footnotetext{
${ }^{4}$ In Slovakia, the subject of ethics is realized as an alternative to religious education. It is a compulsory elective subject at both primary and secondary levels of education - ISCED2 and ISCED3.
} 
Finally, we should not forget the most important ability of ethics and teacher training in ethics education graduates, which is the ability to see the world and social issues (including environmental) from the ethical and moral perspective; an optics of philosophical-ethical rationality and ethical argumentation. Environmental problems and environmentaleducational topics are assessed in the context of good and evil, moral values, norms or principles, concrete ethical theories and methodologies. Among other things, there is the outstanding predisposition of graduates to perform moral and further education tuition - to change the world through formation of moral attitudes, personalities of pupils and the neighbourhood in a spirit of ecologically positive behaviour. Let's not forget the skill to search for and come up with solutions to ethical and moral problems in practice (can be applied in a projection of teaching of environmental education; or in the position of a school coordinator of environmental education).

\section{Acknowledgement}

This paper is a part of the research project - KEGA 005PU-4/2014 Nové výzvy pre učitel'a etickej výchovy v 21. storočí (New challenges for Ethics teacher in the $21^{\text {st }}$ century).

Adela Lešková Blahová is a researcher at the Institute of Ethics and Bioethics. From the scientific and research perspective, she focuses on the application of Ethics of Social Consequences in medicine (including biomedical research), on ethical analysis of environmental problems, on environmental education and also on socio-political issues. She is a member of the Executive Board and the Secretary of the UNESCO Chair in Bioethics.

\section{Corresponding author:}

Adela Lešková Blahová, Institute of Ethics and Bioethics, University of Prešov, 17. Novembra 1, SK-08078 Prešov (Slovakia)

email: adela.leskova-blahova@unipo.sk

\section{References}

ARISTOTLE (2000): Nicomachean ethics. Cambridge: Cambridge University Press.

ČINČERA, J. (2007): Environmentální výchova: od cílů k prostředkům [Environmental education: from aims to means]. Brno: Paido.

LEOPOLD, A. (1999): Obrázky z chatrče a rozmanité poznámky [Pictures from a shack and miscellaneous notes]. Tulčík: Abies.

LEŠKOVÁ BLAHOVÁ, A. (2014): Výchova k environmentálnym hodnotám ako súčast' etickej výchovy [Education to environmental values as part of ethics education]. In: V. Bilasová (ed.): Etické zošity 1: Význam etickej teórie v príprave učitel'a etickej výchovy [Ethical workbooks 1: An importance of ethics education in ethics education teacher training]. Prešov: FF PU, pp. 97-119.

LEŠKOVÁ BLAHOVÁ, A. (2015): The relevance and role of environmental values in ethics education (in the context of environmental ethics). In: Ethics \& Bioethics (in Central Europe), 5(1-2), pp. 41-49.

LEŠKOVÁ BLAHOVÁ, A. (2011): Environmentálna výchova bez (environmentálnej) etiky? [Environmental education without (environmental) ethics?] [online]. In: M. Dupkalová \& I. Ištvan (eds.): Medzinárodná vedecká elektronická konferencia pre doktorandov, vedeckých pracovnikov a mladých vysokoškolských učitelov [International scientific conference for PhD students, researchers and young university teachers]. Prešov: Prešovská univerzita v Prešove, pp. 544-549 [Retrieved October 5, 2014]. Available at: 
http://www.pulib.sk/elpub2/FHPV/Istvan1/pdf_doc/4sekcia/Leskova\%20Blahova.pdf LIBROVÁ, H. (1994): Pestři a zelení (kapitoly o dobrovolné skromnosti) [Bright and green (chapters on voluntary simplicity)]. Brno: Veronica a Duha.

MILOVÁ, S., MEDAL, R. \& KLOCOKOVÁ, J. (2012): Environmentálna výchova a vzdelávanie detí a mládeže - aktuálna situácia na Slovensku. Záverečná správa z výskumu [Environmental education and education of children and youth - current situation in Slovakia. Final research report] [online]. Bratislava: Iuventa, apríl 2012 [Retrieved 2 November 2014]. Available at:

http://www.iuventa.sk/files/documents/7_vyskummladeze/vyskum/2012/z\%C3\%A1vere\%C4 $\% 8 \mathrm{Dn} \% \mathrm{C} 3 \% \mathrm{~A} 1 \% 20 \mathrm{spr} \% \mathrm{C} 3 \% \mathrm{~A} 1 \mathrm{va} . \mathrm{pdf}$

PLATKOVÁ OLEJÁROVÁ, G. (2010): Aktuálne výzvy mravnej výchovy [Current challenges of moral education]. In: V. Gluchman a kol. Filozofická etika (Etika I.) [Philosophical ethics (Ethics I)]. Prešov: Grafotlač, pp. 151-174.

ZELINA, M. (1997): Ako sa stat' tvorivým. Metódy a formy tvorivého riešenia problémov [How to become creative: Methods and forms for creative solutions to problems]. Šamorín: Fontana.

Štátny vzdelávací program - Environmentálna výchova (prierezová téma) [The National Educational Program - Environmental education (cross-sectional topic)] [online]. (2009). Štátny pedagogický ústav, máj 2009 [Retrieved 2 November 2014]. Available at: http://www.statpedu.sk/files/documents/svp/prierezove_temy/environmentalna_vychova.pdf ZAJAC, L. \& NÁVOJSKÝ, A. (eds.) (2014): Učíme sa v globálnych súvislostiach. Koncept globálneho vzdelávania v školách [We learn in a global context: A concept of global education at schools]. Bratislava: Človek v ohrození, o.z.

ZELINA, M. (2010): Teórie výchovy alebo hladanie dobra [Theories of education or a search for good]. Bratislava: SPN. 